\title{
PERANCANGAN SISTEM INTERAKTIF BERBASIS WEB DALAM DIAGNOSA PENYAKIT INFEKSI VIRUS PADA ANAK (STUDI KASUS : UPT. PUSKESMAS KUTA UTARA)
}

\author{
Wayan Riyan Hedriant \\ Prodi Perekam Medis dan Informasi Kesehatan, \\ Universitas Dhyana Pura, Badung, Bali \\ riyan.hedriant@gmail.com
}

\begin{abstract}
The development of information technology is growing up into the world of health. With the technology in the world will facilitate the health services to patients. Information systems can help health workers to do its job quickly then if done manually.Viral diseases are very vulnerable children. This disease will be easier to attack when the child's immune system decreases. Increasingly evolve the viral infections in children will require a rapid handling by health workers, system built to help health workers to know the types of viral infections in children by providing early diagnosis based on symptoms experienced by sufferers. This interactive system designed using web based programming language PHP and uses a database of MYSQL. The purpose of this interactivity system design is to produce a web-based system in the early diagnosis of viral infections in children. Application of this interactive system is to leave the question in the form of symptoms or complaints experienced by the patient, then the system will make the process of analysis based on a percentage likelihood of a diagnosis of the patient's illness. This interactive system will help provide the diagnosis of viral infections in children as well as provide information about the disease as well as the solution of the disease. This system will assist in the provision of services more quickly to patients .
\end{abstract}

Keywords : Interactive Systems, Disease Diagnosis Virus Infection In Children, Web

\begin{abstract}
ABSTRAK
Perkembangan teknologi informasi semakin berkembang hingga ke dunia kesehatan. Dengan adanya teknologi dalam dunia kesehatan akan mempermudah dalam melakukan pelayanan kepada pasien. Sistem informasi dapat membantu petugas kesehatan dalam melakukan pekerjaanya dengan cepat dibandingakan jika dilakukan secara manual. Penyakit akibat virus sangat rentan terjadi pada anak-anak. Penyakit ini akan mudah menyerang saat daya tahan tubuh anak menurun. Semakin berkembanganya penyakit infeksi virus pada anak akan membutuhkan suatu penanganan yang cepat oleh petugas kesehatan.Sebuah sistem dibangun membantu petugas kesehatan untuk mengetahui jenis penyakit infeksi virus pada anak dengan memberikan diagnosa awal berdasarkan gejala yang di alami oleh penderita. Sistem interaktif ini di rancang berbasis web dengan menggunakan bahasa pemrograman PHP dan menggunakan database dari MYSQL. Tujuan dari perancangan sistem interakif ini adalah untuk menghasilkan sistem berbasis web dalam diagnosa awal penyakit infeksi virus pada anak.Penerapan sistem interaktif ini adalah dengan memberikan pertanyaan berupa gejala-gejala atau keluhan yang di alami oleh pasien, lalu sistem ini akan melakukan proses analisis berdasarkan presentase kemungkinan dari diagnosa dari penyakit pasien tersebut. Sistem interaktif ini akan dapat membantu memberikan hasil diagnosa penyakit infeksi virus pada anak serta memberikan keterangan tentang penyakit serta solusi dari penyakit tersebut. Sistem ini akan membantu dalam pemberian pelayanan yang lebih cepat pada pasien.
\end{abstract}

Kata Kunci : Sistem Interaktif, Diagnosa Penyakit Infeksi Virus pada Anak, Web 


\section{PENDAHULUAN}

Teknologi dan Informasi saat ini sudah sangat luas dalam penggunaanya, tidak hanya dalam instansi-instansi pemerintah, perbankan, namun dalam pelayanan kesehatan teknologi dan informasi sudah menjadi bagian penting. Komputer merupakan alat bantu yang memudahkan dalam pengolahan data menjadi informasi, maupun penunjang dalam sistem pengambilan keputusan, sehingga dapat meningkatkan pelayanan kesehatan. Begitu pentingnya suatu data informasi bagi suatu perusahaan, Rumah Sakit, Puskesmas maupun unit pelayanan lainya, maka pengolahan data informasi dengan menggunakan sistem informasi komputer diharapkan dapat mempercepat pengolahan data bagi user (pengguna).

Salah sistem informasi yang dimanfaatkan sebagai pendukung keputusan dapat disebut sebagai sistem interakif yang merupakan suatu bidang ilmu kecerdasan buatan. Kecerdasan buatan (Artificial Intelligence) adalah kegiatan menyediakan mesin seperti komputer dengan kemampuan untuk menampilkan perilaku yang dianggap cerdas jika diamati manusia. Konsep sistem sistem interakif ini didasarkan pada asumsi bahwa pengetahuan dari seorang ahli dibidangnya seperti dokter dapat disimpan dan diaplikasikan ke dalam komputer, kemudian diterapkan oleh orang lain saat dibutuhkan. Dengan pengimplementasian sistem interakif ini ke dalam komputer, dapat menghasilkan beberapa manfaat seperti keakurasian, kecepatan, dan dapat diakses kapan pun sehingga dapat meringankan tugas. Pengimplementasian sistem interaktif pada dunia kesehatan dapat berupa diagnosa penyakit, konsultasi penjaggan kesehatan sampai pemberian saran penentuan solusi dari hasil diagnosa yang ada.

Dengan metode konvensional (mendeteksi gejala secara manual tentang apa yang dirasakan pasien) akan memakan waktu yang sangat lama dan masalahnya sekarang bukan hanya perlu mengetahui penyebab penyakit tetapi yang penting adalah mengetahui dengan cepat penyakit yang diderita serta penanggulangannya, agar penyakit yang diderita oleh anak tidak berdampak dan dapat segera diobati. Tujuan pengembangan sistem ini sebenarnya bukan untuk menggantikan peran manusia tetapi untuk mensubsitusikan pengetahuan manusia ke dalam bentuk sistem, sehingga dapat digunakan oleh petugas kesehatan pelayanan kesehatan dalam memberikan diagnosa awal terhadap kondisi yang sedang dialami pasien. Dengan menggunakan sistem interaktif ini diharapkan dapat mempercepat dalam mendiagnosa suatu jenis penyakit akibat infeksi virus pada anak. Selain itu data yang diperoleh dari hasil pemeriksaan dapat disimpan dalam bentuk komputerisasi sehingga mempermudah dalam pencarian kembali bila data tersebut dibutuhkan kembali.

\section{TINJAUAN PUSTAKA}

\section{Pengertian Perancangan Sistem}

Perancangan sistem adalah penentuan proses dan data yang dilakukan oleh sistem baru. Jika sistem itu berbasiskan komputer, rancangan dapat menyertakan spesifikasi jenis peralatan yang digunakan.

\section{Pengerian Interaktif}

Interakif berasal dari kata interaksi, yaitu hal saling melakukan aksi, berhubungan, mempengaruhi, antar hubungan. Interaksi terjadi karena adanya hubungan sebab akibat, yaitu adanya aksi dan reaksi. Pengertian interaktif adalah hal yang terkait dengan komunikasi dua arah atau suatu hal bersifat saling melakukan aksi, saling aktif dan saling berhubungan serta mempunyai timbal balik antara satu dengan yang lainnya.

\section{Sistem Informasi}

Sistem informasi adalah suatu sistem dalam suatu organisasi yang mempertemukan kebutuhan pengolahan transaksi harian yang mendukung fungsi operasi organisasi yang bersifat manajerial dengan kegiatan strategi dari suatu organisasi untuk dapat menyediakan kepada pihak luar tertentu dengan informasi yang diperlukan untuk pengambilan keputusan. Sistem informasi adalah kerangka kerja yang meng- 
koordinasikan sumber daya (manusia, komputer) untuk mengubah masukan (input) menjadi keluaran (informasi), guna mencapai sasaran-sasaran perusahaan. Sistem informasi juga dapat dijelaskan sebagai suatu sistem didalam suatu organisasi yang mempertemukan kebutuhan pengolahan transaksi harian, mendukung operasi, bersifat manajerial dan kegiatan strategi dari suatu organisasi dan menyediakan pihak luar tertentu dengan laporan-laporan yang diperlukan.

\section{Sistem Pendukung Keputusan}

Sistem Pendukung Keputusan (SPK) adalah sistem berbasis computer interaktif, yang membantu para pengambil keputusan untuk menggunakan data dan berbagai model untuk memecahkan masalah-masalah tidak terstruktur.

Mendefinisikan sistem pendukung keputusan merupakan sistem informasi interaktif yang menyediakan informasi, pemodelan dan manipulasi data. Sistem itu digunakan untuk membantu pengambilan keputusan dalam situasi yang semiterstruktur dan situasi tidak terstruktur, dimana tak seorang pun tahu secara pasti bagaimana keputusan seharusnya dibuat.

Sama dengan para ahli lainnya Turban dkk, mendefinisikan sistem pendukung keputusan sebagai sekumpulan prosedur berbasis model untuk data pemrosesan dan penilaian guna membantu para manajer mengambil keputusan. Dari beberapa definisi diatas dapat dikatakan bahwa sistem pendukung keputusan adalah suatu sistem informasi spesifik yang ditujukan untuk membantu dalam pengambilan keputusan berkaitan dengan persoalan yang bersifat semiterstruktur.

\section{Aplikasi}

Aplikasi adalah suatu penerapan, menyimpan sesuatu hal, data, permasalahan pekerjaan kedalam suatu sarana atau media yang digunakan untuk menerapkan atau mengimplementasikan hal atau permasalahan tersebut sehingga berubah menjadi suatu bentuk yang baru tanpa menghilangkan nilai - nilai dasar dari hal, data, permasalahan atau pekerjaan

\section{Database}

Basis data (database) adalah kumpulan dari berbagai data yang saling berhubungan satu dengan lainnya. Basis data tersimpan di perangkat keras, serta dimanipulasi dengan menggunakan perangkat lunak. Pendefinisian basis data meliputi spesifikasi dari tipe data, struktur, dan batasan dari data atau informasi yang akan disimpan. Database merupakan salah satu komponen yang penting dalam sistem informasi, karena merupakan basis dalam menyediakan informasi pada para pengguna. Penyusunan basis data meliputi proses memasukkan data kedalam media penyimpanan data, dan diatur dengan menggunakan perangkat Sistem Manajemen Basis Data (Database Management System $D B M S$ ).

\section{Data Flow Diagram (DFD)}

Data Flow Diagram (DFD) merupakan bentuk notasi yang dapat digunakan untuk membantu pemahaman mengenai tingkat kompleksitas suatu sistem secara logis. DFD dapat membantu menggambarkan sistem tanpa mempertimbangkan lingkungan fisik dari sistem tersebut Dalam menggambarkan suatu sistem, DFD menggunakan simbol-simbol tertentu untuk mendefinisikan setiap bagian dari sistem. Simbol-simbol tersebut diantaranya : (1) External Entity (2) Data Flow (3) Process (4) Data Store.

MySQL

MySQL adalah salah satu jenis database server yang sangat terkenal. Kepopulerannya disebabkan MySQL menggunkaan SQL sebagai bahasa dasar untuk mengakses databasenya. Selain itu bersifat free (tidak perlu membayar untuk menggunakannya). MySQL termasuk jenis RDBMS (Relational Database Management System). Itulah sebabnya istilah seperti tabel, baris, dan kolom digunakan pada MySQL. Pada MySQL, sebuah database mengandung 
satu atau sejumlah tabel. Tabel terdiri dari sejumah baris dan setiap baris mengandung satu atau beberapa kolom.

MySQL merupakan perangkat lunak yang dapat digunakan untuk pengolahan database berbasis client-server. MySQL menyediakan bahasa pemograman SQL (Structure Query Language). MySQL menyediakan banyak fungsi, mulai dari manipulasi tanggal, angka, string, dan sebagainya. MySQL sanggup melakukan pengolahan data dalam jumlah banyak.

MySQL mempunyai kekurangan diantaranya adalah database ini tidak portable sebagaimana database Acces yang langsung bisa dipindah-pindahkan. Untuk memindahkan data pada MySQL harus dilakukan eksport terlebih dahulu baru kemudian di import ketempat atau komputer baru sehingga terkesan agak lama.

\section{Bahasa Pemrograman}

Bahasa pemrograman adalah perangkat lunak atau software yang dapat digunakan dalam proses pembuatan program yang melalui beberapa tahapan-tahapan penyelesaian masalah.

\section{Infeksi Virus Pada Anak}

Anak merupakan individu yang berada dalam satu rentang perubahan perkembangan yang dimulai dari bayi hingga remaja. Pada dasarnya penyakit pada anak dapat disebabkan oleh banyak faktor. Pada umumnya penyebanya adalah virus. Virus adalah organisme yang amat halus. Karena amat halusnya itu tidak dapat dilihat dengan mikroskop biasa. Untuk itu diperlukan suatu mikroskop electron yakni mikroskop yang mampu membesarkan sampai 1.000.000 X. Jenis-jenis virus yang dapat menimbulkan penyakit-penyakit yakni cacar, gondongan, influenza, selesma atau Common Cold dan lain sebagainya.

Penyakit infeksi virus ini sangat rentan terjadi pada anak-anak, karena sistem imunitas pada tubuh anak belum terbangun secara sempurna. Lingkungan juga menjadi faktor yang mempengaruhi rentannya suatu penyakit infeksi virus menyerang anak.
Anak-anak yang tumbuh di lingkungan padat dengan udara dan sanitasiburuk lebih rentan terserang penyakit dan akan menurunkan imunitas tubuh pada anak. Penyakit infeksi virus akan mudah menjangkit anak-anak dengan imunitas yang lemah. Sebagai contoh penyakit infeksi virus yang sering terjadi pada anak adalah campak, varicella simlex, mumps (gondongan), rubella dan beberapa penyakit lainnya.

\section{METODE DAN PERANCANGAN SISTEM}

\section{Kerangka Berpikir}

Untuk membantu dalam membuat perancangan sistem interakif dalam diagnosa penyakit infeksi virus pada anak ini, maka perlu dilakukan suatu analisa dengan tahapan sebagai berikut :

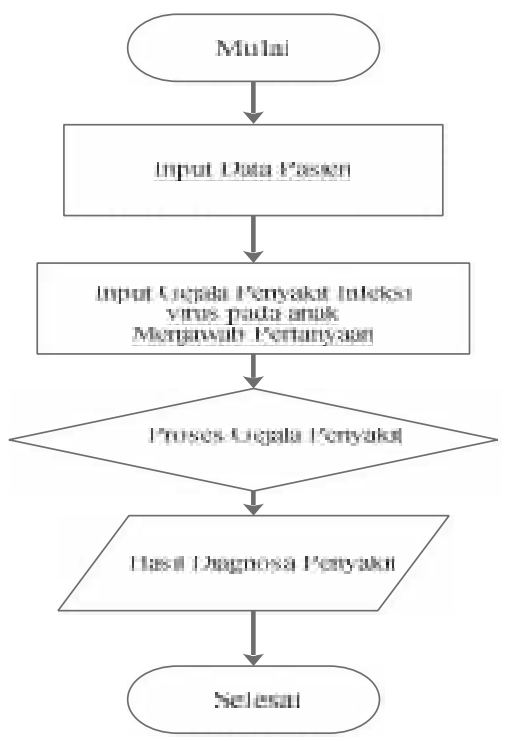

Gambar 1. Kerangka Berpikir

\section{Metode Penelitian}

Dalam melakukan penelitian metode yang digunakan untuk perancangan sistem interaktif diagnosa penyakit infeksi virus pada anak ini adalah dengan menerapkan siklus hidup pengembangan sistem (Systems Development Life Cycle-SDLC) atau sering kali disebut sebagai pendekatan air terjun (waterfall approach) yang meliputi tahap perencanaan, tahap analisis, tahap desain, tahap implementasi, dan tahap penggunaan. 


\section{Desain Sistem}

Pada tahap desain sistem hal yang harus dilakukan untuk membuat sistem yang akan dibangun adalah dengan menggunakan rancangan DFD (Data Flow Diagram) dan Desain tampilan antar muka (Interface).

\section{Diagram Aliran Data}

Diagram Aliran Data/Data Flow Diagram (DFD) adalah sebuah teknis grafis yang menggambarkan aliran informasi dan transformasi yang diaplikasikan pada saat data bergerak dari input menjadi output.

DFD dapat digunakan sebagai media dalam merepresentasikan sebuah sistem perangkat lunak pada level abstraksi. DFD dapat dibagi menjadi beberapa level yang lebih detail untuk merepresentasikan aliran data atau fungsi yang lebih detail (DFD bertingkat/levelled).

\section{Diagram Konteks}

Diagram konteks merupakan gambaran secara umum mengenai sebuah sistem yang dirancang secara global, yaitu suatu diagram yang mempersentasikan atau mengambarkan hubungan antara sistem dengan lingkungan luar sistem yang mempengaruhi operasi sistem. Sistem ditunjukan dalam satu lingkungan yang mengambarkan keseluruhan proses dalam sistem dan hubungannya dengan entitas. Terdapat sebuah entitas yang terhubung langsung dengan sistem yaitu pengguna (user). Adapun Diagram konteks pada sistem pakar ini dapat dilihat pada gambar dibawah ini.

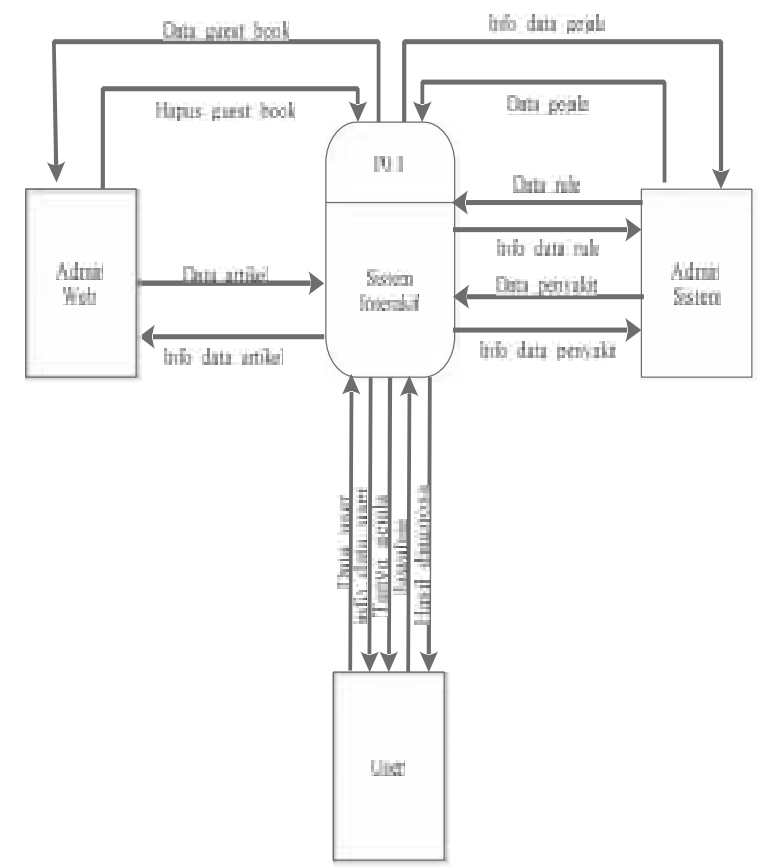

Gambar 2 Diagram Konteks

\section{DFD Level 0}

Data Flow Diagram (DFD) adalah diagram alir yang dipresentasikan dalam bentuk lambang-lambang tertentu yang menunjukan aliran data, proses, tempat penyimpanan data, dan entitas eksternal. Data Flow Diagram dibuat untuk mengetahui suatu proses dari diagram konteks yang di buat dalam penjabaran yang lebih umum dan dibagi dalam beberapa proses. 


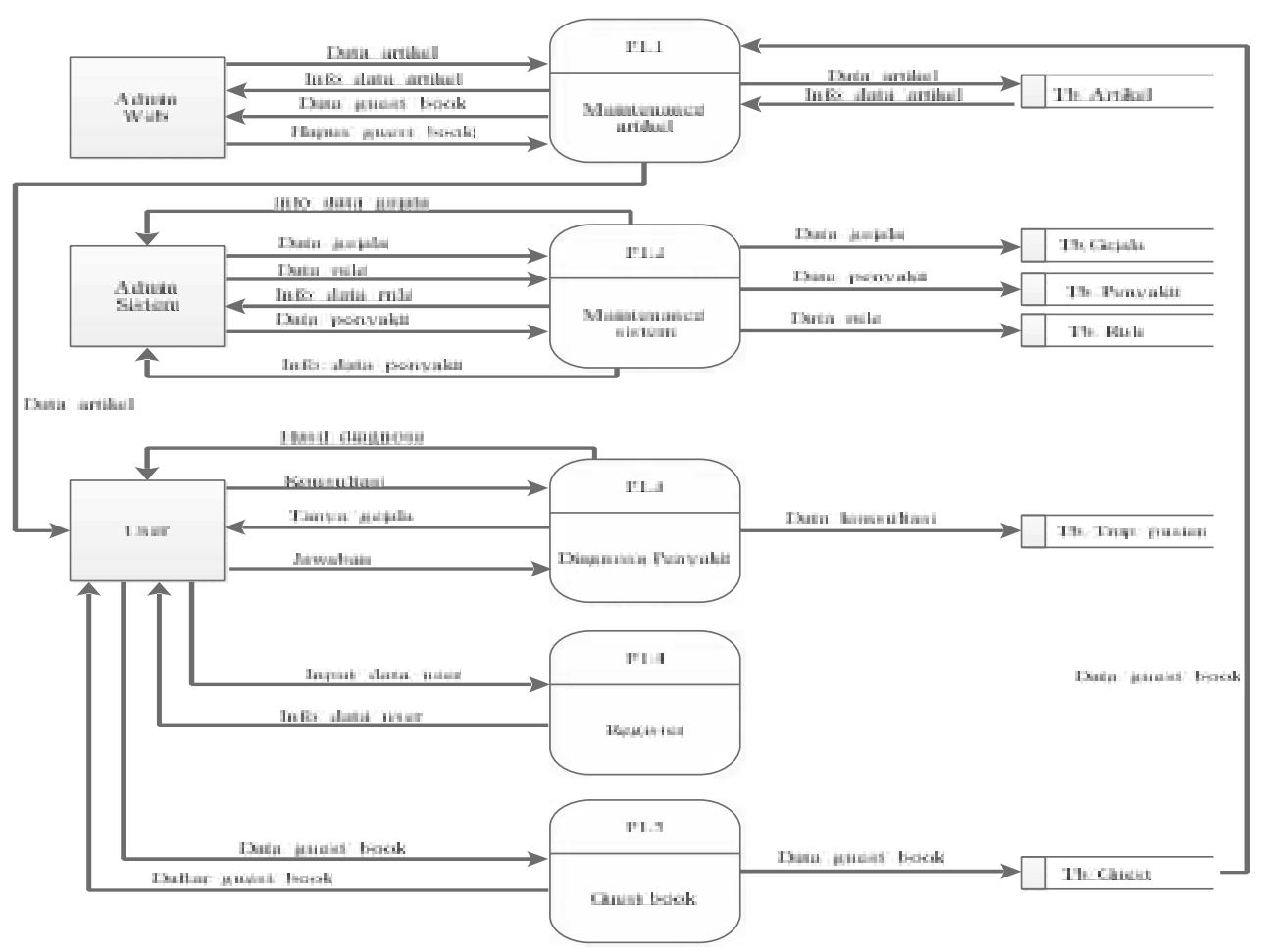

Gambar 3. DFD Level 0

\section{ERD (Entity Relationship Diagram)}

Diagram relasi entitas, seperti ditunjukan oleh namanya, berhubungan dengan data di dalam entitas dan hubungan antar entitas. Ketika pengguna dan spesialis informasi mulai untuk berkomunikasi tentang kebutuhan data untuk suatu sistem informasi, mereka akan berbicara mengenai pengumpulan field-field data yang saling berhubungan, field-field yang saling berhubungan ini disebut entitas. Hubungan (relasi) antara data : one to many

1. Satu penyakit memiliki banyak rule

2. Satu gejala memiliki banyak rule

3. Satu tmp_gejala memiliki banyak gejala

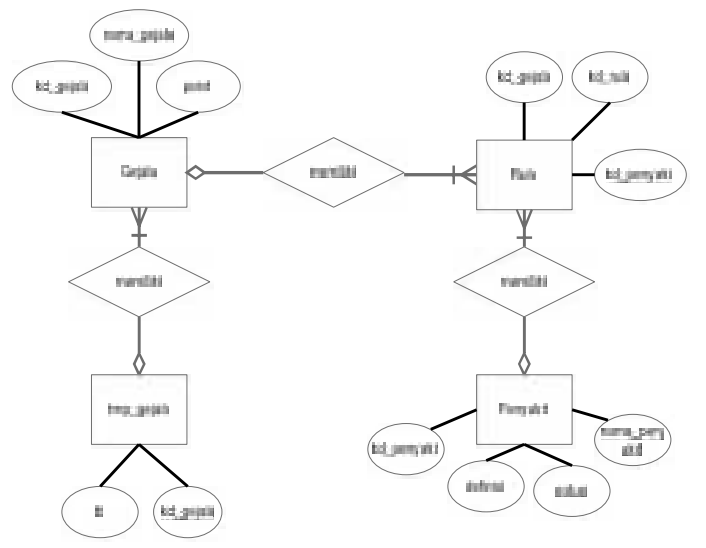

Gambar 4 ERD (Entity Relationship
Diagram) 


\section{IMPLEMENTASI SISTEM}

\section{Kebutuhan Sistem}

Aplikasi sistem ini memerlukan perangkat lunak (software) dan perangkat keras (hardware) agar dapat berjalan sesuai dengan harapan. Karena aplikasi ini merupakan aplikasi berbasis web, maka terdiri dari komputer web server dan komputer client sebagai pengakses.

Perangkat lunak untuk komputer server adalah sebagai berikut :

a. Sistem operasi menggunakan Microsoft Windows 8.

b. Apache web server versi 2.0 atau lebih

c. PHP 5.2.6 + PHP 4.4.9 + PEAR

d. MYSQL database versi 5.0.51 atau lebih.

Perangkat untuk perangkat keras untuk web server minimal menggunakan :

a. Processor Core 2 Duo $1 \mathrm{GHz}$ atau lebih

b. Harddisk 250GB atau lebih

c. Memory RAM 1GB atau lebih

d. VGA $128 \mathrm{MB}$ atau lebih.

Perangkat lunak yang digunakan oleh komputer client adalah :

a. Sistem Operasi Microsoft Windows 8

b. Mozila Firefox 2.7 atau lebih, Chrome, Internet Exploler dan software browser lainnya.

Sedangkan perangkat keras untuk komputer client :

a. Processor Core 2 Duo $1 \mathrm{GHz}$ atau lebih

b. Harddisk 250GB atau lebih

c. Memory RAM 1GB atau lebih

d. VGA 280MB atau lebih

e. Modem atau koneksi internet dengan kecepatan 64Kbps atau lebih

f. Mouse dan keyboard

\section{Teknik Pemrograman}

Sistem Interakif untuk mendukung keputusan ini dikembangkan menggunakan PHP, Dreamweaver dan diimplementasikan dengan sistem operasi windows 8 serta menggunakan Web Server Apache, PHP sebagai sarana dalam pengembangan dan implementasi sistem interaktif ini, dengan alasan :

1. PHP merupakan aplikasi berbasis web sehingga dapat dibuka menggunakan web browser saja dan tidak diperlukan proses instalasi dikomputer client yang akan menggunakan aplikasi ini.

2. Karena PHP pemrograman berbasis web, maka dapat diakses dari mana saja ketika sistem ini telah dihosting pada sebuah web server. Sedangkan dalam perancangan database dibuat dengan menggunakan MYSQL5. Hal ini dilakukan karena MYSQL5 dapat dengan mudah berintegrasi dengan pemrograman PHP.

\section{Implementasi Sistem}

Implementasi adalah tahap penerapan dan pengujian untuk suatu sistem berdasarkan hasil analisa dan perancangan yang telah dilakukan pada bab III. Maka pada bab IV merupakan bagian untuk melakukan pengimplementasian dari hasil rancangan menjadi sebuah aplikasi Sistem Interaktif barbasis web dalam Diagnosa Penyakit Infeksi Virus Pada Anak dengan menggunakan database MySQL.

\section{Antar Muka Sistem (Interface)}

Tampilan antar muka merupakan gambaran mengenai tampilan sistem yang telah dibuat. 
1. Halaman Menu Utama

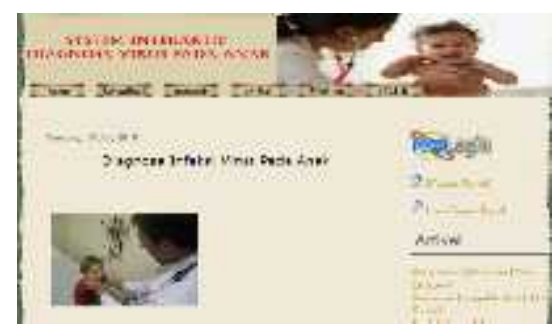

Gambar 5 Halaman Menu Utama

2. Halaman Menu Konsultasi

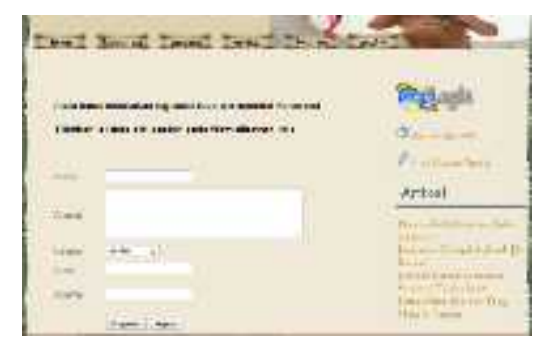

Gambar 6 Halaman Menu Konsultasi

3. Halaman Menu Pertanyaan

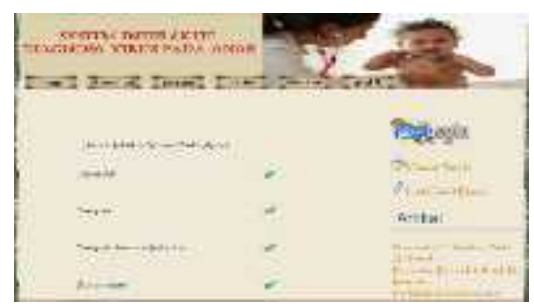

Gambar 7 Halaman Menu Pertanyaan

4. Halaman Hasil Analisis Penyakit

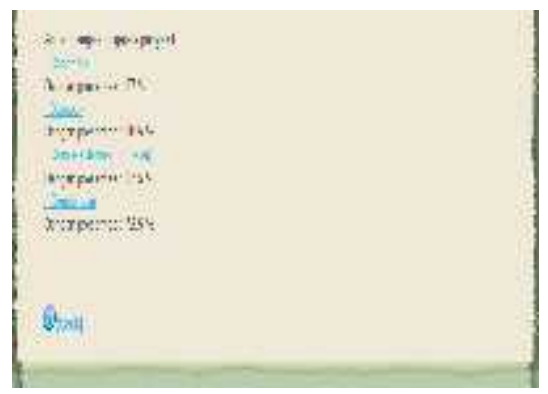

Gambar 8 Halaman Hasil Analisis Penyakit
5. Halaman Menu Info Penyakit

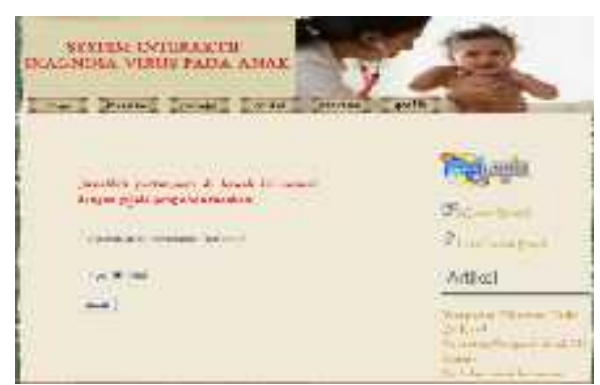

Gambar 9 Halaman Menu Info Penyakit

6. Halaman Menu Artikel

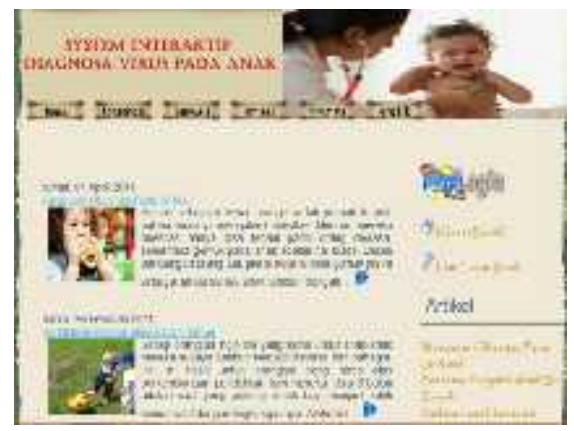

Gambar 10 Halaman Menu Artikel

7. Halaman Menu Grafik

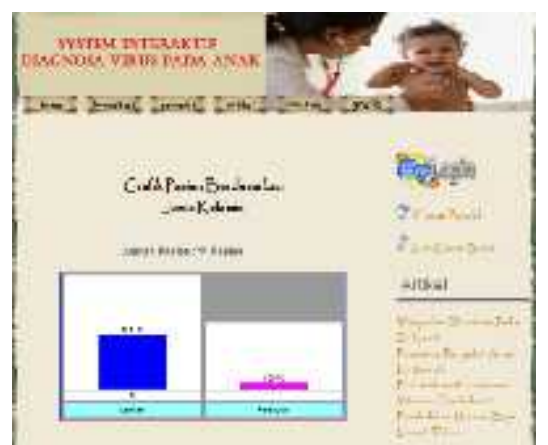

Gambar 11 Halaman Menu Grafik 


\section{SIMPULAN}

Sistem interaktif ini merupakan sistem yang dirancang dan dibangun dengan teknologi berbasis web. Sistem ini dapat memberikan kemudahan dalam memberikan diagnosa awal penyakit infeksi virus pada anak.

Sistem ini memberikan banyak manfaat bagi petugas kesehatan dalam memberikan pelayanan kepada pasien khususnya pasien anak. Sistem dapat membantu petugas kesehatan dalam memberikan pelayanan kepada pasien dengan cepat dan tepat.

\section{DAFTAR PUSTAKA}

[1] Aden, R. 2010. Seputar Penyakit dan Gangguan Lain Pada Anak. Yogyakarta: Hanggar Kreator.

[2] Alimul Hidayat,A.Aziz. 2005. Pengantar ilmu keperawatan anak 1., Jakarta: Salemba Medika.

[3] Bambang Warsita. (2008). Teknologi Pembelajaran, Landasan dan Aplikasinya. Jakarta: Rineka Cipta.

[4] Jogiyanto Hartono M, 2005. Analisis dan Desain Sistem Informasi : Pendekatan Terstruktur Teori dan Praktek Aplikasi Bisnis.

Yogyakarta: Andi

[5] Kadir, Abdul., 2003. Pengenalan Sistem Informasi. Yogyakarta : ANDI.

[6] Kusrini,. 2007. Konsep dan Aplikasi Sistem Pendukung Keputusan. Yogyakarta: ANDI OFFSET.

[7] McLeod, Raymond ,Jr. 2001. Sistem Informasi. Edisi 7 Jilid 2. Prenhallindo. Jakarta

[8] Turban, Efraim Aranson, Jae E, and Liang, Tim Peng. 2005, Decision Support System and System Intelegence. 7th Edition, jilid 1, Penerbit ANDI 